Abstracta Iranica Abstracta Iranica

Revue bibliographique pour le domaine irano-aryen

Volume 27 | 2006

Comptes rendus des publications de 2004

\title{
A History of the Ancient East ca. 3000-323 BC. Oxford, 313 p., 28 ill. noir et blanc et 16 cartes, 17 « boxes » et 13 documents.
}

\section{Astrid Nunn}

\section{(2) OpenEdition}

Journals

Édition électronique

URL : http://journals.openedition.org/abstractairanica/5620

DOI : 10.4000/abstractairanica.5620

ISSN : 1961-960X

Éditeur :

CNRS (UMR 7528 Mondes iraniens et indiens), Éditions de l'IFRI

\section{Édition imprimée}

Date de publication : 15 mai 2006

ISSN : 0240-8910

Référence électronique

Astrid Nunn, «A History of the Ancient East ca. 3000-323 BC. Oxford, 313 p., 28 ill. noir et blanc et 16 cartes, 17 «boxes » et 13 documents. », Abstracta Iranica [En ligne], Volume 27 | 2006, document 38, mis en ligne le 02 janvier 2007, consulté le 25 septembre 2020. URL : http://journals.openedition.org/ abstractairanica/5620 ; DOI : https://doi.org/10.4000/abstractairanica.5620

Ce document a été généré automatiquement le 25 septembre 2020.

Tous droits réservés 


\title{
A History of the Ancient East ca. 3000-323 BC. Oxford, 313 p., 28 ill. noir et blanc et 16 cartes, 17 «boxes » et 13 documents.
}

\author{
Astrid Nunn
}

1 La première question à résoudre est de savoir ce qu'est le Proche Orient ancien. L'A. se base surtout sur les sources textuelles - celles classiques du premier millénaire sont incluses - chronologiques, géographiques et accessoirement archéologiques. Le livre débute avec Uruk et la formation des cités et passe en revue les différentes périodes jusqu'à la troisième partie qui est consacrée aux empires du premier millénaire av. J.-C. Les chapitres 11 à 15 commencent par une revue du Proche Orient ancien vers l'an 1000 puis traitent l'empire néo-assyrien, les Mèdes et les Babyloniens (pp. 253-266) et enfin l'empire perse (pp. 267-280). La civilisation orientale propre se termine en Babylonie avec l'avènement d'Alexandre le Grand. Le chapitre sur l'empire achéménide prend la place qui lui est due dans un aperçu sur 3000 ans d'histoire. Le texte, tout en évoquant les aspects principaux sur la politique et l'économie des Grands Rois, est informatif et dense mais néanmoins succinct.

2 Ce livre est une excellente introduction à l'histoire du Proche Orient ancien et s'adresse aussi bien à des étudiants qu'à un public intéressé.

\section{INDEX}

Thèmes : 3.0. Généralités 


\section{AUTEURS}

\section{ASTRID NUNN}

Université de Munich 